\title{
Analysis of Genetic Parameters on Mutant Populations of Mungbean (Vigna radiata L.) after Ethyl Methane Sulphonate Treatment
}

\author{
Rajib ROYCHOWDHURY',2*, Sudipta DATTA' ${ }^{1}$, Parineeta GUPTA ${ }^{1}$, Jagatpati TAH ${ }^{1}$ \\ ${ }^{1}$ The University of Burdwan, Cytogenetics and Plant Breeding Laboratory, Botany Department (UGC-CAS), Burdwan-713104, West Bengal, India. \\ ${ }^{2}$ Visva Bharati, Center for Biotechnology, School of Life Science, Santiniketan-731235, West \\ Bengal, India; rajibroychowdhurybu@gmail.com ('corresponding author)
}

\begin{abstract}
In the present study, pure line seeds of mungbean (Vigna radiata L. Wilczek) were treated with four doses $(0.2 \%, 0.4 \%, 0.6 \%$ and $0.8 \% \mathrm{as} \mathrm{w} / \mathrm{v}$ ) of ethyl methane sulphonate (EMS) to analyse the genetic variability and heritability for some prime agro-metrical traits in second mutant $\left(\mathrm{M}_{2}\right)$ generation. The analysis of variance revealed highly significant differences among the studied characters $(\mathrm{P}<0.01)$. The phenotypic coefficient of variation (PCV) was higher than its genotypic counterpart (GCV) for all the studied traits. The highest GCV $(0.537)$ for number of seeds per pods and highest PCV (0.635) for plant height were recorded in 0.4\% EMS treatment. The lowest GCV (0.179) and PCV (0.214) were recorded in the control set for number of pods per plant. The highest broad sense heritability estimate (92.33\%) was recorded on 0.4\% EMS for plant height. The expected genetic advance was high (42.39\%) in $0.4 \%$ dose for days to flowering. The lowest heritability (38.43) and genetic advance (5.37) were noticed in control for the total seed yield per plant. EMS at $0.4 \%$ and $0.6 \%$ concentration gave the maximum values of all the genetic parameters. The increased genetic variability in treated population for these traits has a high scope for selection and can be exploited for the further improvement of mungbean.
\end{abstract}

Keywords: chemical mutagen, heritability, selection response, variability, yield component

Abbreviations: ANOVA-Analysis of variance, CD-Critical difference, CV-Coefficient of variation, EMS-Ethyl methane sulphonate, GA-Genetic advance, GCV-Genotypic coefficient of variation, $\mathrm{H}^{2}$-Heritability in broad sense, $\mathrm{M}_{1}$-First mutant generation, $\mathrm{M}_{2}$-Second mutant generation, MSS-Mean sum of square, NPK-Nitrogen Phosphate Potassium, PCV-Phenotypic coefficient of variation, SEStandard error

\section{Introduction}

Mungbean (Vigna radiata L. Wilczek), belongs to the angiospermic dicot family: Papilionaceae, is an important self-fertile pulse crop of South-Eastern Asia and occupy a pivotal position in meeting the protein needs of people in developing countries like India (Wani and Khan, 2006). This pulse crop is widely grown in India, Pakistan, Bangladesh, Sri Lanka and Thailand. It is also known as the crop of sub-continent and up to three crops per year can be grown (Malik, 1994). Diversifying the limited genetic variability for agronomic traits of interest, especially yield and its associate attributes and developing new mungbean cultivars are demand of this modern era. Due to lack of sufficient natural variability for yield and its component traits in V.radiata, conventional methods of breeding have limited scope. Induced mutations have been used to generate genetic variability and have been successfully utilized to improve yield and yield components of various crops like Oryza sativa (Singh et al., 1998), Dianthus caryophyllus (Roychowdhury and Tah, 2011a), Vicia faba (Ismail et al., 1977), Vigna unguiculata (Mensah and Akomeah, 1992), Cajanus cajan (Srivastava and Singh, 1996), Vigna mungo (Singh and Singh, 2001) and Lens culinaris (Khan et al., 2006). These reports show that mutagenesis is a potential tool to be employed for crop improvement.

The knowledge of the extent to which the desirable attributes are heritable is a prerequisite for any crop improvement programme, especially for mutation breeding. For this purpose, inducible mutation is a suitable source of producing variation through mutation breeding procedure (Domingo et al., 2007) which can produce several improved mutant varieties with high demanding economic values (Din et al., 2004). Various metrical traits with agro-economic value like seed weight, number of branches, leaves, flowers, leaf area, etc. are very much complex in nature because they confirm polygenic inheritance and greatly influenced by minute fluctuation of environmental components (Roychowdhury et al., 2011b). Genetic improvement of any crop is largely depending on the magnitude of several genetic parameters like analysis of variance of each mean value, phenotypic and genotypic variance, phenotypic and genotypic coefficient of variation (PCV and GCV), broad sense heritability $\left(\mathrm{H}^{2}\right)$ and genetic advance (GA) on which the breeding methods are formulated for its further improvement (Roychowdhury et al., 2011b). Development of high-yielding varieties requires a thorough knowledge of the existing genetic variation 
138

and heritability of agronomic traits and their interrelationship which helps in understanding yield components and yield potential in mungbean (Wani and Khan, 2006). The observed variability is a combined estimate of genetic and environmental causes, of which only the former one is heritable. Assessment of genetic variation is the most appropriate statistical tool to find out the magnitude of heritability, genetic coefficient of variation and response to selection using appropriate selection intensity for traits of interest (Roychowdhury et al., 2011b). Analysis on genetic variability reveals about the presence of variation in their genetic constitution, and it is of outmost important as it provides the basis for the scope of effective selection (Pandey et al., 2010). Wide spectrum of genetic variability has been induced in Vigna radiata using both chemical and physical mutagens in order to utilize it in pulsecrop improvement and inheritance studies (Ashri, 1970; Gowda et al., 1996; Patil, 1966). The extent of variability is measured by genotypic coefficient of variance (GCV) and phenotypic coefficient of variance (PCV) which provides information about relative amount of variation in different characters. Hence, to have a thorough comprehensive idea, it is necessary to have and analytical assessment of metrical traits. Since heritability is also influenced by environmental factors, the information on heritability alone may not help in pin pointing characters enforcing selection. Makeen et al. (2007) evaluated mungbean genotypes to estimate genetic variability, heritability and genetic advance for agronomic characters and reported highly significant differences for all traits with greater magnitude of heritability for plant height and seed weight. Similarly, Siddique et al. (2006) reported highly significant genetic variation for days to flowering, maturity, pods per plant and seed yield among their studied mungbean genotypes. Rohman et al. (2003) reported that plant height and days to flowering were mostly governed by additive genes effects. Sriphadet et al. (2005) reported 89.9, 98.9, 93.7 and 93.2\% heritability for leaves number per plant, seed hardness, pod-length and pod-width, respectively. Seed yield is reported to be positively correlated with traits like days to flowering, plant height, branches per plant, pods per plant and pod-length. Malik (1994) have reported positive cor- relation of number of pods and branches per plant with seed yield. Similarly, Khan et al. (2001) reported strong association among branches per plant and pods per plant leading to increased yield per unit area. Positively and statistically significant relationship between seed yield per plant and days to $50 \%$ flowering, pods per plant, seeds per plant, harvest index and 1000 seed weight is reported by Celal (2004). However, estimates of heritability alone do not provide an idea about the expected gain in the next generation, but have to be considered in conjunction with estimates of genetic advance, the change in mean value between generations (Johnson et al., 1955). Simply, heritability gives the information on the magnitude of inheritance of metrical attributes, i.e. polygenic inheritance, while genetic advance will be helpful in formulating suitable selection procedures.

In the present study, therefore, an attempt has been made to determine the genetic variation, its components, especially phenotypic coefficient of variation (PCV) and genotypic coefficient of variation (GCV), broad-sense heritability $\left(\mathrm{H}^{2}\right)$ and genetic advance (GA) for yield and its associate components in $\mathrm{M}_{2}$ generations of mungbean. These estimates could be useful in developing reliable selection indices for important agronomic traits of Vigna radiata.

\section{Materials and methods}

The seeds of experimental plant material (Vigna radiata L. Wilczek) were obtained from Globe Nursery, Kolkata. The field experimentation was conducted during the June-September of 2009 at the Crop Research Farm, The University of Burdwan, Burdwan, India. Information regarding the meteorological characteristics like temperature, seasonal rainfall, relative humidity, geographical position, etc. of the test location is given in Tab. 1.

As per the protocol of Roychowdhury and Tah (2011b), seeds of mungbean were treated with four different concentrations $(0.2 \%, 0.4 \%, 0.6 \%$ and $0.8 \%$ as $\mathrm{w} / \mathrm{v})$ of potent chemical mutagen: ethyl methane sulphonate (EMS) to induce mutations. The untreated seeds presoaked in distilled water and were sown as control. One

Tab. 1. Meteorological characteristics like temperature, seasonal rainfall, relative humidity, wind speed, geographical position, altitude and soil type about the test location used for evaluation of mungbean treatments/genotypes in 2009

\begin{tabular}{|c|c|c|c|c|c|c|c|c|}
\hline Parameter & \multicolumn{2}{|c|}{ June } & \multicolumn{2}{|c|}{ July } & \multicolumn{2}{|c|}{ August } & \multicolumn{2}{|c|}{ September } \\
\hline \multirow{2}{*}{ Average temperature $\left({ }^{\circ} \mathrm{C}\right)$} & $\operatorname{Max}$ & Min & $\operatorname{Max}$ & Min & $\operatorname{Max}$ & Min & Max & Min \\
\hline & 39.2 & 28.1 & 42.1 & 29.5 & 38.8 & 27.6 & 34.6 & 26.3 \\
\hline Average rainfall $(\mathrm{mm})$ & \multicolumn{2}{|c|}{65} & \multicolumn{2}{|c|}{69} & \multicolumn{2}{|c|}{51} & \multicolumn{2}{|c|}{42} \\
\hline \multirow{2}{*}{ Relative humidity } & Max & Min & Max & Min & Max & Min & Max & Min \\
\hline & 79 & 51 & 82 & 59 & 68 & 46 & 64 & 41 \\
\hline Wind speed $(\mathrm{km} / \mathrm{h})$ and direction & \multicolumn{2}{|c|}{ 8.1, $S$ and $S E$} & \multicolumn{2}{|c|}{ 7.2, SE and NE } & \multicolumn{2}{|c|}{ 6.4, NE and $\mathrm{S}$} & \multicolumn{2}{|c|}{ 6.4, SE and $\mathrm{N}$. } \\
\hline Latitude & \multicolumn{8}{|c|}{$23.53^{\circ} \mathrm{N}, 22.56^{\circ} \mathrm{S}$} \\
\hline Longitude & \multicolumn{8}{|c|}{$83.25^{\circ} \mathrm{E}, 86^{\circ} \mathrm{W}$} \\
\hline Elevation (m.s.l.) & \multicolumn{8}{|c|}{$45 \mathrm{~m}$} \\
\hline Soil type and $\mathrm{pH}$ & \multicolumn{8}{|c|}{ Neutral (pH 6.6-7.3) } \\
\hline
\end{tabular}


hundred seeds for every treatment and control were sown in the field in a randomized complete block design with three replicates to raise the first mutant $\left(M_{1}\right)$ generation. Plot size for a mungbean treatment in each replication was $3.5 \mathrm{~m}^{2}$. Each plot had $3 \mathrm{~m}$ long three rows with row to row and plant to plant distance of $50 \mathrm{~cm}$ and $30 \mathrm{~cm}$, respectively. Such a field design is most frequently used in plant breeding programmes (Mensah and Tope, 2007). Soil test of field for available nutrients was carried out prior sowing the plant seeds through Soil Testing Lab, Gov. of West Bengal, Cooch Behar, India (Tab. 2). Based on the soil analysis, 20\% Zinc sulphate as $30 \mathrm{~kg} / \mathrm{ha}$ and NPK as 50:100:50 kg/ha were applied as a basal dose during final land preparation in experimental field. Urea (nitrogen source), di-ammonium phosphate $\left(\mathrm{P}_{2} \mathrm{O}_{5}\right.$ source $)$ as phosphate fertilizer and potash sulphate $\left(\mathrm{K}_{2}^{2} \mathrm{O}^{5}\right.$ source $)$ as potassium fertilizer were also applied before the seed sowing. Required amount of chemical fertilizers was applied at the time of soil preparation. Pesticides were sprayed to protect the crop from pests especially white fly, a vector for Mungbean Yellow Mosaic Virus.

For raising $M_{2}$ generation, ten $M_{1}$ progenies were selected which showed significant deviations in mean values in the positive direction from the mean values of the control, particularly for the yield and its associate components. Seeds from each selected $M_{1}$ progeny were bulked and thoroughly mixing them (Wani and Khan, 2006). A random sample of this bulk was sown to obtain $\mathrm{M}_{2}$ progeny. Three replications of each $M_{2}$ mungbean treatment were maintained in the experimental field. Normal recommended cultural practices and plant protection measures were followed. Data collected for plant height $(\mathrm{cm})$ at maturity, days to flowering, pods per plant, seeds per pods and seed yield ( $\mathrm{g}$ ) per plant in the $\mathrm{M}_{2}$ generation were sub- jected to statistical analysis in order to assess the extent of induced variation due to mutagenic action. Significant differences were identified using the Least Significance Difference estimated from the error mean square and tabulated ' $t$ '-values at the $1 \%$ level of significance.

For statistical analysis of genetic parameters, it was considered the analysis of variance of each mean value (Tab. 3), coefficient of variation (CV), critical difference (CD), phenotypic and genotypic variance, phenotypic and genotypic coefficient of variation (PCV and GCV), broad sense heritability $\left(\mathrm{H}^{2}\right)$ and genetic advance (GA). Mean values were subjected to analysis of variance to test the significance for each traits as per Panse and Sukhatme (1967).

Phenotypic and genotypic variances were estimated according to Lush (1940). The genotypic and phenotypic coefficients of variation (GCV and PCV) were computed according to the method advocated by Singh and Chaudhary (1985). Heritability in broad sense was determined according to the methodology given by Allard (1960). The estimate of the expected genetic advance (GA) expressed as a percentage of the mean value with an assumed 5\% (2.06 after Kang et al., 1983) intensity of selection pressure was computed by the formula given by Singh and Chaudhary (1985) as: $\mathrm{GA}=\mathrm{k} . \mathrm{H}^{2} . V_{\sigma}$; where, $\mathrm{k}=2.06$, constant for $5 \%$ selection intensity (i.e. the highest-performing $5 \%$ are selected), $\mathrm{H}^{2}=$ broad-sense heritability, $\sigma_{\mathrm{g}}=$ genotypic variance of the treated population.

\section{Results and discussion}

The estimate of mean, maximum and minimum range, mean sum of square (MSS), F-value, coefficient of variation (CV), critical difference (CD) for five studied met-

Tab. 2. Soil characteristics and available macro and micro elements/nutrients based on soil test of experimental location

\begin{tabular}{ccccc}
\hline Parameters & & Actual amount & Status & Threshold level \\
\hline Organic Carbon $(\%)$ & & 1.37 & High & 0.75 \\
Available $\mathrm{P}_{2} \mathrm{O}_{5}(\mathrm{~kg} / \mathrm{ha})$ & & 76 & High & $22.5-56$ \\
\hline & $\mathrm{N}$ & 789 & High & $217-544 \mathrm{~kg} / \mathrm{ha}$ \\
Macro elements & $\mathrm{K}$ & 296 & Adequate & $125-283 \mathrm{~kg} / \mathrm{ha}$ \\
& $\mathrm{P}$ & 18.7 & Adequate & $3-20 \mathrm{ppm}$ \\
\hline & $\mathrm{Ca}$ & 24.83 & Adequate & $10-40 \mathrm{meq} / 100 \mathrm{~g}$ \\
& $\mathrm{Mg}$ & 6.1 & Adequate & $5-15 \mathrm{meq} / 100 \mathrm{~g}$ \\
\hline \multirow{2}{*}{ Micro elements } & $\mathrm{Bo}$ & Low & $\leq 0.7 \mathrm{ppm}$ \\
& $\mathrm{Fe}$ & $0.46-0.51$ & Adequate & $\leq 4.5 \mathrm{ppm}$ \\
\hline Exchangeable $\mathrm{Na}(\mathrm{mM} / 100 \mathrm{~g})$ & $\mathrm{Zn}$ & $1.3-1.5$ & Adequate & $\leq 1.0 \mathrm{ppm}$ \\
\hline Dissoluble salt $\mathrm{EC}(\mathrm{dS} / \mathrm{m})$ & 16.5 & Adequate & 15 \\
\hline
\end{tabular}

Tab. 3. Analysis of variance

\begin{tabular}{|c|c|c|c|c|}
\hline Source & d.f. & Sum of Square (SS) & Mean Sum of Square (MSS) & Expectations \\
\hline Treatment $(\mathrm{t})$ & $t-1$ & $\mathrm{SS}_{\mathrm{t}}$ & $\mathrm{SS}_{\mathrm{t}} / \mathrm{t}-1$ & $\mathrm{MSS}_{\mathrm{t}} / \mathrm{MSS}_{\mathrm{c}}$ \\
\hline Replication (r) & $\mathrm{r}-1$ & $\mathrm{SS}_{\mathrm{r}}$ & $\mathrm{SS}_{\mathrm{r}} / \mathrm{r}-1$ & $\mathrm{MSS}_{\mathrm{r}} / \mathrm{MSS}_{\mathrm{c}}$ \\
\hline Error $(\mathrm{e})$ & $(\mathrm{t}-1)(\mathrm{r}-1)$ & $\mathrm{SS}_{\mathrm{c}}$ & $\mathrm{SS}_{\mathrm{c}} /(\mathrm{t}-1)(\mathrm{r}-1)$ & \\
\hline
\end{tabular}

d.f. = degree of freedom, $S S=$ Total sum of square, MSS = Mean sum of square, $g=$ number of genotypes or treatments, $r=$ no. of replications 
140

rical attributes in mungbean treatments are given in Tab. 4. Analysis of variance showed that the genotypes differed significantly $(\mathrm{P}<0.01)$ for all the studied characters $(\mathrm{Tab}$. 4) which indicate that the treatments were genetically divergent after mutagenic treatment. There is a huge scope for selection of promising mutant lines with different metrical attributes from the present gene pool. Similar result was reported by Sirohi and Kumar (2006) in mungbean. The highest mean value (63.5) was noticed for plant height at maturity followed by days to flowering (56.34) and the lowest mean value (8.62) was for seeds per plant. Mean sum of square (MSS) for all the characters studied were significant at the probability of $1 \%$ level. The range of F-value was 12.478-61.928 indicated that this range follows the magnitude of mean values for all attributes. The coefficient of variation ( $\mathrm{CV}$ as percentage) indicated that there were significant differences among the treatments for the characters under study. It also reveals that the value of $\mathrm{CV}$ ranges from 5.66 for days to flowering to 9.31 for pods per plant. All the CV values for five metrical attributes were below the value of 10. Rahim et al. (2008) also found medium to high CV for days to maturity and days to $50 \%$ flowering. The significant critical difference (CD) values indicate that Vigna radiata L. 'Wilczek' cultivar was suitable for the location where prevailing environmental effects were favourable. The higher $\mathrm{CD}$ value indicates the higher stability in that environment (Roychowdhury, 2011; Roychowdhury et al., 2011c). Here, days to flowering showed higher $C D$ value (3.78), plant height at maturity showed moderate (2.54) and seed yield (g) per plant represented lower CD value, i.e. 0.76. Significant genetic variation for morphological traits like days to flowering, maturity and plant height is also reported by Rohman et al. (2003), Siddique et al. (2006) and Rozina et al. (2008) in mungbean.

The estimation of mean, genotypic (GCV) and phenotypic (PCV) coefficient of variation, broad sense heritability $\left(\mathrm{H}^{2}\right)$ and genetic advance $(\mathrm{GA})$ of mungbean treatments are given in Tab. 5. A wide range of variation in studied five traits was observed with regard to control and four different doses of EMS. There was a significant increase in the mean values and genetic variability of studied characters in all the mutagenic treatments over the control in $\mathrm{M}_{2}$ generation. In the present study, increase in the mean values of various traits may be due to the selection of normal-looking plants in $\mathrm{M}_{2}$ which led to the elimination of aberrant plants and also due to changes induced at genetic level. Gaul (1964) suggested that the selection process should be delayed until the $\mathrm{M}_{3}$ or later generations following mutagenic treatment. However, here the selection of progenies was on the basis of desirable mean and greater variance in the early generation was found to be highly useful, leading to the desirable improvement of yield and its components. Here, the increase in the number of pods was due to an increase in the number of flowers. Flower shedding was not noticed in the mutants. Similar increases in the number of pods of some other varieties of mungbean have been reported by Tickoo and Chandra (1999) using EMS, nitroso-methyl urea (NMU), hydroxyl-amine (HA) and gamma rays as mutagens. In most of all cases, it was noticed that with the increase in EMS concentration, the mean value rises over control for its respective traits like as plant height, days to flowering, pods per plant, seeds per pods, total seed yield per plant, etc. The magnitude of mean values for all traits are: $0.4 \% \mathrm{EMS}>0.6 \% \mathrm{EMS}>$ CONTROL $>0.2 \%$ EMS $>0.8 \%$ EMS for plant height, $0.8 \% \mathrm{EMS}>0.6 \% \mathrm{EMS}>0.4 \% \mathrm{EMS}>0.2 \% \mathrm{EMS}>$ CONTROL for days to flowering, $0.6 \%$ EMS $>0.4 \%$ EMS $>0.2 \%$ EMS $>0.8 \%$ EMS $>$ CONTROL for pods per plant, $0.4 \%$ EMS $>0.6 \%$ EMS $>$ CONTROL $>0.8 \%$ EMS $>0.2 \%$ EMS for seeds per pods, $0.6 \%$ EMS $>0.4 \%$ EMS $>0.2 \%$ EMS $>0.8 \%$ EMS $>$ CONTROL for seed yield per plant. Only, days to flowering showed complete sequentially increase in mean value from control to lower EMS dose (0.2\%) to its higher doses accordingly. It proved that EMS treatment inhibits early flowering according to its increasing doses by causing gene mutation. For most of characters, $0.6 \%$ and $0.4 \%$ EMS dose were responsible for giving the highest value.

In general, the phenotypic coefficient of variation (PCV) was higher than its genotypic counterpart (GCV) for all the studied characters. This resemblance between PCV and GCV in almost all the characters suggests that the environment had little effect on those characters' expression and was consistent with Jagaonkar et al. (1990). The GCV provides a measure for comparing genetic variability in various metrical characters. The highest GCV (0.537) for seeds per pods and highest PCV (0.635) for plant height were recorded in $0.4 \%$ EMS treatment. Lowest GCV (0.179) and PCV (0.214) were recorded in control for pods per plant. For plant height, GCV/ PCV was highest $(0.506 / 0.635)$ in $0.4 \% \mathrm{EMS}$ and lowest

Tab. 4. Mean, standard error (S.E.), maximum and minimum range, mean sum of square (MSS), coefficient of variance (CV \%) and critical difference (CD) values for metrical attributes in mungbean (Vigna radiata L.) treatments

\begin{tabular}{cccccc}
\hline Characters & Mean \pm S.E. & Range $($ Min-Max $)$ & MSS & CV\% & CD \\
\hline Plant height $(\mathrm{cm})$ at maturity & $63.5 \pm 2.36$ & $58.6-69.4$ & $110.76^{* *}$ & 7.62 & 2.54 \\
Days to flowering & $56.34 \pm 0.93$ & $48.4-64.9$ & $14.92^{* *}$ & 5.66 & 3.78 \\
Pods per plant & $32.98 \pm 0.72$ & $25.48-37.38$ & $86.40^{* *}$ & 9.31 & 1.92 \\
Seeds per pods & $8.62 \pm 1.04$ & $7.31-9.66$ & $1.96^{* *}$ & 8.46 & 3.61 \\
Seed yield $(\mathrm{g})$ per plant & $15.19 \pm 0.19$ & $12.40-16.93$ & $21.37^{* *}$ & 9.14 & 0.76 \\
\hline
\end{tabular}

${ }^{* *}$ indicates significant at $1 \%$ level of significance 
Tab. 5. Different genetic parameters viz. genotypic and phenotypic coefficient of variation (GCV and PCV), heritability $\left(\mathrm{H}^{2}\right)$ and genetic advance (GA) as percent of mean of five prime agro-metrical traits for EMS treated mungbean populations

\begin{tabular}{|c|c|c|c|c|c|c|}
\hline \multirow{2}{*}{ Characters } & \multirow{2}{*}{ Parameters } & \multicolumn{5}{|c|}{ Treatments } \\
\hline & & Control & $0.2 \%$ EMS & $0.4 \%$ EMS & $0.6 \%$ EMS & $0.8 \%$ EMS \\
\hline \multirow{5}{*}{ Plant height $(\mathrm{cm})$} & $\operatorname{Mean}(\mathrm{X}) \pm$ S.E. & $63.3 \pm 2.62$ & $61.7 \pm 3.31$ & $69.4 \pm 3.34$ & $64.5 \pm 3.66$ & $58.6 \pm 3.89$ \\
\hline & GCV\% & 0.392 & 0.266 & 0.506 & 0.416 & 0.197 \\
\hline & PCV\% & 0.441 & 0.339 & 0.635 & 0.498 & 0.283 \\
\hline & $\mathrm{H}^{2} \%$ & 76.32 & 81.65 & 92.33 & 88.43 & 83.92 \\
\hline & GA as $\%$ of $\mathrm{X}$ & 18.24 & 21.43 & 27.48 & 25.77 & 23.81 \\
\hline \multirow{5}{*}{ Days to flowering } & $\operatorname{Mean}(X) \pm$ S.E. & $48.4 \pm 0.88$ & $52.6 \pm 0.63$ & $56.5 \pm 0.79$ & $59.3 \pm 0.37$ & $64.9 \pm 0.94$ \\
\hline & GCV\% & 0.239 & 0.283 & 0.317 & 0.375 & 0.408 \\
\hline & PCV\% & 0.248 & 0.312 & 0.366 & 0.433 & 0.480 \\
\hline & $\mathrm{H}^{2} \%$ & 66.35 & 73.73 & 90.12 & 82.66 & 87.38 \\
\hline & GA as $\%$ of $X$ & 36.36 & 38.28 & 42.39 & 40.71 & 41.55 \\
\hline \multirow{5}{*}{ Pods per plant } & $\operatorname{Mean}(\mathrm{X}) \pm$ S.E. & $25.48 \pm 0.55$ & $33.23 \pm 0.83$ & $37.14 \pm 0.85$ & $37.38 \pm 0.62$ & $31.65 \pm 0.62$ \\
\hline & GCV\% & 0.179 & 0.224 & 0.297 & 0.299 & 0.198 \\
\hline & PCV\% & 0.214 & 0.283 & 0.386 & 0.391 & 0.248 \\
\hline & $\mathrm{H}^{2} \%$ & 43.81 & 51.59 & 59.32 & 59.78 & 46.55 \\
\hline & GA as $\%$ of $\mathrm{X}$ & 8.77 & 10.78 & 12.06 & 12.63 & 9.96 \\
\hline \multirow{5}{*}{ Seeds per pod } & $\operatorname{Mean}(\mathrm{X}) \pm$ S.E. & $8.94 \pm 1.07$ & $7.31 \pm 1.12$ & $9.66 \pm 1.02$ & $9.10 \pm 1.23$ & $8.08 \pm 1.17$ \\
\hline & GCV\% & 0.439 & 0.413 & 0.537 & 0.498 & 0.424 \\
\hline & PCV\% & 0.505 & 0.468 & 0.612 & 0.586 & 0.482 \\
\hline & $\mathrm{H}^{2} \%$ & 58.86 & 56.32 & 76.88 & 66.55 & 62.74 \\
\hline & GA as $\%$ of $\mathrm{X}$ & 26.92 & 24.57 & 34.73 & 32.21 & 30.18 \\
\hline \multirow{5}{*}{ Seed yield $(\mathrm{g})$ per plant } & $\operatorname{Mean}(\mathrm{X}) \pm$ S.E. & $12.40 \pm 0.12$ & $15.20 \pm 0.20$ & $16.74 \pm 0.24$ & $16.93 \pm 0.19$ & $14.66 \pm 0.18$ \\
\hline & GCV\% & 0.266 & 0.321 & 0.346 & 0.354 & 0.288 \\
\hline & PCV\% & 0.332 & 0.398 & 0.412 & 0.424 & 0.366 \\
\hline & $\mathrm{H}^{2} \%$ & 38.43 & 41.86 & 44.13 & 42.68 & 40.12 \\
\hline & GA as $\%$ of $\mathrm{X}$ & 5.37 & 7.24 & 8.86 & 7.97 & 6.98 \\
\hline
\end{tabular}

$(0.197 / 0.283)$ in $0.8 \%$ EMS, whereas for days to flowering, the highest value $(0.408 / 0.480)$ in $0.8 \%$ EMS and lowest value $(0.239 / 0.248)$ in control. Seeds per pods showed maximum GCV/PCV $(0.537 / 0.612)$ in $0.4 \%$ EMS and minimum $(0.413 / 0.468)$ in $0.2 \%$ EMS. In case of pods and seed yield per plant, highest GCV/PCV $(0.299 / 0.391$ and $0.354 / 0.424$, respectively) was recorded in $0.6 \% \mathrm{EMS}$ and lower value $(0.179 / 0.214$ and $0.266 / 0.332)$ in control. It was observed that most of the lowest GCV and PCV were encountered in control, whereas $0.4 \%$ and $0.6 \%$ EMS were responsible for its highest value. High values of GCV suggested better improvement for selection of traits. However, the estimation of heritable variation with the help of genetic coefficient of variation alone may be misleading. Burton $(1951,1952)$ suggested that the genetic coefficient of variation together with heritability estimates gave a better picture of the extent of heritable variation. Heritability $\left(\mathrm{H}^{2}\right)$ and genetic advance (GA) estimates were interpreted as low, medium and high as per the classification of Johnson et al. (1955).

The values of heritability increased and differed from trait to trait. Highest broad sense heritability estimate (92.33\%) was observed with $0.4 \%$ EMS for plant height. The expected genetic advance was high (42.39\%) with same treatment ( $0.4 \%$ EMS ) for days to flowering. Low- est heritability (38.43) and genetic advance (5.37) were noticed in control for seed yield per plant. Kaul and $\mathrm{Ku}-$ mar (1983) obtained low heritability values for grain yield in rice. The high estimates of heritability in the metrical traits has been found to be useful from the point of view of plant breeding, as this enables selection to be based on phenotypic performance. The ranges of heritability in each character according to lower magnitude were: 76.32 (Control)-92.33 (0.4\% EMS) for plant height, 66.35 (Control)-90.12 (0.4\% EMS) for days to flowering, 56.32 (0.2\% EMS)-76.88 (0.4\% EMS) for seeds per pods, 43.81 (Control)-59.78 (0.6\% EMS) for pods per plant and 38.43 (Control)-44.13 (0.4\% EMS) seed yield per plant. Most of the control plants show lower value of heritability and $0.4 \%$ EMS was responsible for giving its higher value. High heritability was recorded for plant height and days to flowering, moderate heritability for seeds per pods and low for seed yield and pods per plant. Roychowdhury and Tah (2011a) also reported high heritability for plant height and moderate for seeds per inflorescence in case of Dianthus caryophyllus. High heritability combined with high genetic advance as percent of mean was observed in $0.4 \%$ EMS for days to flowering. This indicates the lesser influence of environment in the expression of this character and prevalence of additive gene action in its inheri- 
142

tance, hence amenable for simple selection. High heritability with moderate genetic advance as per cent of mean was recorded in $0.6 \%$ and $0.8 \%$ EMS for days to flowering indicating that this character was governed by additive gene interaction. High heritability coupled with low genetic advance as per cent of mean was recorded in all EMS treatment, especially $0.4 \%$ EMS for plant height indicating non-additive gene action for this trait. Miah and Bhadra (1989) reported high values for expected genetic advance for seeds per pods. Makeen et al. (2007) and Sriphadet et al. (2005) have also reported moderate to high heritability for various morphological traits in mungbean. Due to high heritability estimates, the traits are expected to remain stable under varied environmental conditions and could easily be improved through selection (Khattak et al., 1997; Siddique et al., 2006).

\section{Conclusions}

With regards to genetic parameters, variability was higher in EMS treatments than the control set. The values of the coefficients of variation (phenotypic and genotypic), heritability and expected genetic advance increased in the treated population as compared to control. EMS at $0.4 \%$ and $0.6 \%$ concentration gave the maximum values of the genetic parameters. High heritability was observed for plant height and days to flowering indicated that in the present material, the scope of improvement for these traits by simple selection would be effective. High heritability coupled with high genetic advance expected in the next generation for days to flowering suggesting this character was governed by additive genetic effect to a great extent and improvement of it would be effective through selection. But, plant height expressed non-additive gene interaction, hence it needs to be complex selection process and heterosis breeding would be recommended.

\section{References}

Allard RW (1960). Principles of plant breeding. John Wiley and Sons, New York, USA, 89-98 p.

Ashri A (1970). A dominant mutation with variable penetrance and expressivity induced by diethyl sulfate in peanuts (Arachis hypogaea L.). Mut Res 9:473-480.

Burton GW (1951). Quantitative inheritance in Pearl millet ( $P$. glaucum). Agron J 43:409-417.

Burton GW (1952). Quantitative inheritance in grasses. $6^{\text {th }}$ Int Grassland Cong 1:277-283.

Celal Y (2004). Correlation and path coefficient analysis of seed yield components in the narbon bean (Vicia narbonensis L.). Turk J Agric 28:371-376.

Din R, Qasim M, Ahmad K (2004). Radio sensitivity of various wheat genotypes in $M_{1}$ generation. Int J Agric Biol 6:898900.

Domingo C, Andres F, Talon M (2007). Rice cv. 'Bahia' mutagenized population: a new resource for rice breeding in the Mediterranean basin. Spain J Agric Res 5:341-347.

Gaul H (1964). Mutations in plant breeding. Rad Bot 4:155232.

Jagaonkar R, Jamadagni BM, Salvi MJ (1990). Genetic variability and correlation studies in turmeric. Ind Cocoa, Arecanut Spices J 14(1):20-22.

Johnson HW, Robinson HF, Comstock RE (1955). Estimation of genetic and environmental variability in soybean. Agron J 47:314-318.

Gowda MVC, Nadaf HL, Sheshagiri R (1996). The role of mutation in intraspecific differentiation of groundnut (Arachis hypogaea L.). Euphytica 90:105-113.

Ismail MA, Heakal MY, Fayed A (1977). Improvement of yield through induced mutagenesis in broad beans. Ind J Genet Plant Breed 36(3):347-350.

Kang MS, Mille JD, Tai PYP (1983). Genetic and phenotypic path analysis and heritability in sugarcane. Crop Sci 23:643647.

Kaul MLH, Kumar V (1983). Mutation genetic studies in rice IV Variability components and genetic parameters. Biol Zentralblatt 102:559-566.

Khan M, Nawab K, Khan A, Baloch MS (2001). Genetic variability and correlation studies in mungbean. J Biol Sci 1:117-119.

Khan S, Wani MR, Parveen K (2006). Sodium azide induced high yielding early mutant in lentil. Agric Sci Digest 26(1):65-66.

Khattak GSS, Razi-ud-Din F, Hanan F, Ahmad R (1997). Genetic analysis of some quantitative characters in mungbean. Sarhad J Agric 13(4):371-376.

Lush JL (1940). Intra-sire correlation and regression of offspring on dams as a method of estimating heritability of characters. Proc American Soc Animal Produc 33:293-301.

Makeen K, Abrahim G, Jan A, Singh AK (2007). Genetic variability and correlations studies on yield and its components in mungbean (Vigna radiate L. Wilczek). J Agron 6(1):216-218.

Malik BA (1994). Grain legume, p. 277-328. In: Bashir E, Bantel R (Eds.). Crop production. National Book Foundation, Islamabad, Pakistan.

Mensah JK, Akomeah PA (1992). Mutagenic effects of hydroxylamine and streptomycin on the growth and seed yield of cowpea (Vigna unguiculata L. Walp). Legume Res 15(1):39-44.

Mensah JK, Tope OR (2007). Performance of Mung beans (Vigna mungo L. Hepper) grown in mid-west Nigeria. American-Eurasian J Agric Environ Sci 2 (6):696-701.

Miah NN, Bhadra SK (1989). Genetic variability in the $F_{2}$ generation of mungbean. Bangladesh J Agric Res 14(1):7275.

Pandey P, Anurag PJ, Rangare NR (2010). Genetic parameters for yield and associated characters in Rice. Ann Plant Soil 
Res 12 (1):59-61.

Panse VG, Sukhatme PV (1967). Statistical Methods for Agricultural Workers, $2^{\text {nd }}$ Ed. ICAR publication, New Delhi, India, $381 \mathrm{p}$.

Patil SH (1966). Mutations induced in groundnut by X-rays. Ind J Genet 26A:334-348.

Rahim MA, Mia AA, Mahmud F, Afrin KS (2008). Multivariate Analysis in Some Mungbean (Vigna radiata L. Wilczek) Accessions on the Basis of Agronomic Traits. AmericanEurasian J Sci Res 3(2):217-221.

Roychowdhury R (2011). Effect of Chemical Mutagens on Carnation (Dianthus caryophyllus L.): A Mutation Breeding Approach, $1^{\text {st }}$ Ed. LAP Lambert Academic Publishing, Germany, $14 \mathrm{p}$.

Roychowdhury R, Tah J (2011a). Genetic variability study for yield and associated quantitative characters in mutant genotypes of Dianthus caryophyllus L. Afr Crop Sci J 19(3):183-188.

Roychowdhury R, Tah J, Dalal T, Bandyopadhyay A (2011b). Selection response and correlation studies for metrical traits in mutant Carnation (Dianthus caryophyllus L.) genotypes. Cont J Agric Sci 5(3):6-14.

Roychowdhury R, Bandopadhyay A, Dalal T, Tah J (2011c). Biometrical analysis for some agro-economic characters in $\mathrm{M}_{1}$ generation of Dianthus caryophyllus. Plant Arch 11(2):989-994.

Rohman MM, Hussain ASMI, Arifin SM, Akhter Z, Hasanuzzaman M (2003). Genetic variability, correlations and path analysis in mungbean. Asian J Plant Sci 2:12091211.

Rozina G, Khan H, Mairaj G, Ali S, Farhatullah A, Ikramullah M (2008). Correlation study on morphological and yield parameters of mungbean (Vigna radiata). Sarhad J Agric 24(1):11-16.
Siddique M, Malik MFA, Shahid IA (2006). Genetic divergence, association and performance evaluation of different genotypes of mungbean (Vigna radiata). Int J Agric Biol 8(6):793-795.

Singh RK, Chaudhary BD (1985). Biometrical Methods in Quantitative Genetic Analysis. Kalyani Publishers, Ludhiana, India, $318 \mathrm{p}$.

Singh S, Richharia AK, Joshi AK (1998). An assessment of gamma ray induced mutations in rice (Oryza sativa L.). Ind J Genet Plant Breed 58(4):455-463.

Singh M, Singh VP (2001). Genetic analysis of certain mutant lines of Urdbean for yield and quality traits in $\mathrm{M}_{4}$ generation. Ind J Pulses Res 14(1):60-62.

Sirohi A, Kumar L (2006). Studies on genetic variability, heritability and genetic advance in mungbean (Vigna radiata L. Wilczek). Int J Agric Sci 2(1):174-176.

Sriphadet S, Cristopher JL, Srinives P (2005). Inheritance of agronomic traits and their interrelationship in mungbean (Vigna radiata L. Wilczek). J Crop Sci Biotechnol 10(4):249256.

Srivastava A, Singh VP (1996). Induced high yielding Pigeon pea mutants. Mut Breed Newsletter 42:8-9.

Tickoo JL, Chandra N (1999). Mutagen induced polygenic variability in mungbean (Vigna radiata L. Wilczek). Ind J Genet Plant Breed 59(2):193-201.

Wani MR, Khan S (2006). Estimates of genetic variability in mutated populations and the scope of selection for yield attributes in Vigna radiata (L.) Wilczek. Egypt J Biol 8:1-6. 